\title{
Matching Credit with Season: An Issue for Non Performing Agricultural Loans in Nigeria
}

\author{
${ }^{1}$ Christopher N. Ekong (Ph. D.), ${ }^{2}$ Kenneth U. Onye \\ $\left.{ }^{1,2}\right)$ Department of Economics, Faculty of Social Sciences, University of Uyo, Nigeria
}

\begin{abstract}
This paper empirically investigates the performance of Nigeria's agricultural credit policies with a view to unearthing the factors responsible for the poor loan performance. The findings reveal that although Nigeria's agricultural sector is abysmally underfunded with an unproductive federal budget structure that have been detrimental to agricultural productivity, the basic factor responsible for poor loan performance has been the failure to match credit with seasons. From the analysis of loans and disbursement flow to agricultural sector, it was discovered that loan are paid to farmers with utter disregard to the seasons. Evidently, the mismatch of credit disbursement with seasons attenuated growth and productivity of agriculture in Nigeria, resulting in poor loan performance. We recommend the adoption of the seasonality model, an innovative strategy, which is capable of solving the problem of default in agricultural financing and as such aiding the process of enhanced agricultural productivity and national development.
\end{abstract}

Key Words: agricultural loans, Nigeria, Seasonality Model, ACGSF

\section{Introduction}

Devising appropriate development strategy that will capture the financial services requirement of farmers, especially the poor and small-scale producers, who constitute over 70 percent of the Nigerian population is a major challenge facing the country. The need to develop agriculture cannot be over emphasized as the sector holds the key that drives economic growth, wealth creation and poverty reduction. The sector contributed about $31 \%$ of GDP and $60 \%$ of employment in 2011 (table 1). The Federal and state governments in Nigeria have long recognized the need for sustainable growth and development of the economy through the financial empowerment of farmers. This is based on the understanding that if the growth strategy of raising agricultural productivity through the financial empowerment of farmers is adopted, and the latent capabilities of this large segment of the Nigerian population is sufficiently harnessed and sustained, then positive multiplier will be experienced throughout the economy. To give force to this aspiration, various policies have been instituted by successive administrations to improve the country's agricultural production capabilities and put the sector in the front burner of government development strategy.

Despite barrage of policies targeted at providing low-cost loans to bolster agricultural productivity and seemingly huge government expenditure in the sector, results seem to be scanty. Nigeria was once a large exporter of agricultural products and the sector was the major foreign exchange earner before the discovery of Crude oil in the 1970s. The country is currently a huge net importer of agricultural products, with such imports exceeding \$3 billion in 2010 (GAIN, 2011:2). The performance of agricultural loan in Nigeria appears to be abysmal. But the country has the potential to return to its previous position if adequate attention is given to agricultural credit policies and programmes.

This paper develops a model of agricultural loan disbursement, the seasonality model, which not only offers the most plausible explanation for non-performing agricultural loan facilities in Nigeria, but promises the panacea to agricultural loan delinquency and low productivity. The paper is divided into five sections. Following the introduction, section 2 focuses on government policies and programmes aimed at channeling low-cost funds to the agricultural sector in order boast productivity in the sector. This section also highlights the operations and achievements of these programmes. Section 3 presents and discusses the performance profile of major agricultural credit policies and overall agricultural productivity in Nigeria's history. Section 4 discusses the Seasonality Model (SM). In section 5, we present a summary of major findings and the implication for policy.

\section{Review of Key Government Programmes aimed at Providing Cheap Loans for Agricultural Development in Nigeria}

Government policies to bring credit to the under-banked sector of the economy are biased towards developing agriculture. The policies include the establishment of schemes, programmes, and institutions to address and deliver government's intentions in the sector (Eze et al, 2010:6). Some of these are encapsulated in the national development plan and budgets. But an important instrument used by the Central Bank of Nigeria $(\mathrm{CBN})$ in assisting the financing of agriculture is its credit guideline embodied in its Monetary Policy Circulars 
(MPCs). The first MPC was issued in 1969 and since then, the CBN has consistently given preferential treatment to agriculture. Both the volume of loan allocated to the sector and the interest rate chargeable on such loans are covered by the preferential treatment. In 1985, for instance, the share of agriculture in commercial bank loans and advances to the agricultural sector was increased from $10 \%$ to $12 \%$ to facilitate the increased output expected from the sector (Ike, 1986:411; CBN's MPC, 1985). The current Monetary Policy Circular (MPC no. 39) which covers the 2012/2013 fiscal years also provides that the $40 \%$ interest rebate under ACGSF's Interest Drawback Programme (IDP) shall continue to be paid to farmers (who liquidate their loan that were borrowed at market determined rates as at when due) in 2013.Similarly, under the Agricultural Credit Support Scheme (ACSS), Farmers who pay back their facilities on schedule are to further enjoy a rebate of $6 \%$, thus reducing the effective interest rate from 14\% to 8\% (CBN 2012: MPC no.39, p.40). In terms of government policies to administer low-cost loans for improved agricultural productivity, the following institutions, schemes and programmes are discernable.

\section{1 'Agricultural Institutions' for providing low-cost Credit to Farmers in Nigeria} i. Nigerian Agricultural and Cooperative Bank (NACB) and Nigerian Agricultural, Cooperative and Rural Development Bank (NACRDB)

In order to enable money deposit banks meet the targets set for them in the Monetary Policy Circular, the NACB was established in 1973 as a private limited liability company to provide high level and quality credit to all aspect of agricultural production (including horticulture, poultry farming, pig breeding, fishery, forestry and timber production), enhance the availability of storage facilities, and promote marketing of agricultural products through the liberalization of credit to farmers. According to Ike (1986: 412), the NACB was intended to provide medium to long term financing for agriculture. This was because of the reluctance of commercial banks to provide this type of financing for agriculture and the general mismanagement and abuse which characterized government loans to farmers channeled through the state credit institutions. In 2002, the NACRDB was born out of the merger of NACB, Peoples Bank of Nigeria (PBN), and Family Economic Advancement Programme (FEAP) (Ojiako and Ogbukwa 2012: 2053). As we see in Eze et al (2010: 11), although NACRDB now collect deposits, it has not lived up to expectation due to poor funding.

\section{ii. Nigerian Agricultural Insurance Corporation (NAIC), (1987 to date)}

The NAIC was established to provide insurance cover for all types of farming and farming related activities, including insurance for stock in transit. The premium paid on NAIC policy is heavily subsidized by the CBN to make it affordable for small holder farmers. The indemnity paid in the event of occurrence of a risk that has been insured helps in ploughing the farmer back to business.

\section{iii. Microfinance Banks (2005 to date)}

As we see in GAIN (2012:6), microfinance brings financial services such as savings, deposit, payments, transfers, micro insurance and micro leasing to the active (or productive) poor and low income people, who would otherwise have no access to such services. The Microfinance Policy outlines the principles and guidelines for the practice of microfinance in Nigeria, including provision for the establishment of private sector driven microfinance banks with market-centered operations. A veritable source of loanable funds for microfinance banks is the Micro Credit Fund. The specific objectives of the Nigerian microfinance policy are to:

(a) make financial services accessible to a large segment of the potentially productive Nigerian population which otherwise would have little or no access to financial services;

(b) promote synergy and mainstreaming of the informal subsector into the national financial system;

(c) enhance service delivery by Microfinance institutions to micro, small , and medium entrepreneurs; and (d) contribute to rural transformation and promote linkage programmes between universal and development banks, specialized institutions and microfinance banks.

According to Eze et al (2010: 10), the micro finance banks are of two types; those licensed to operate as a unit bank with capital base of N20 million and those licensed to operate in a state with capital base of N1 billion. Some modest success has been achieved, especially through the MFIs that are supported by NGOs. The limitation with NGO-MFIs is that they are prohibited from mobilizing deposits and find it difficult to grow

(iv) Community banking programme (1991 to 2007)

This programme provided for the establishment of community banks with a focus on rural banking operations. The National Board for Community Banks (NBCB) was the regulator of these banks until 2002 when this function was transferred to the $\mathrm{CBN}$. It was intended to serve communities that were able to establish one based on personal recognition, character and credit worthiness of the borrower. 
Other institutions include the River Basin Development Authority, 1977 to date; Directorate for Foods, Roads and Rural Infrastructure (DFRRI), 1986 to 1993; and People's Bank of Nigeria, 1990 to 2002, among others (Ekong and Onye 2012). The River Basin Development Authority was established in view of the importance of collecting data on River Niger and Benue. It was meant to undertake laboratory analysis of salt and silt water as well as the models of water control projects in the country. This was needful in view of the agricultural and navigational benefits that could be derived from result of such analysis as a basis for planning. DFRRI, established in 1986 through the promulgation of Decree No.4 of 1987, was to construct and maintain rural roads to provide the link between the farm produce and the market, promote agricultural production through the provision of inputs (seedling, fertilizers and equipment) and the provide rural housing. The scheme was unable to meet the set target due to high level of corruption and duplication of functions and was scrapped in 1993. The Peoples of Nigeria was essentially created to provide micro credit of N250, 000 or less to clients (at a service charge of $20 \%$ ) who should have compulsory savings of $30 \%$ of the loan on hand before they can access the facility.

\section{2 'Agricultural Schemes' for Providing Low-cost Credit to Farmers in Nigeria i. Agricultural Credit Guarantee Scheme Fund (ACGSF), (1978 to date)}

In a study conducted in 1976 by the CBN, shortage of primary production credit was identified as one of the major causes of declining agricultural production. The shortage of credit was attributed to reluctance by Banks to lend to the real sector, especially agricultural production due to perceived risk in the sector, high cost of administration of agricultural loans and inability of farmers to provide the necessary collateral, among others. As a probable solution to this problem, the ACGSF was established in 1977 (via Decree No. 20 but started operation in 1978) by the Federal Government of Nigeria (60\%) and CBN (40\%) with an initial Fund of N100 million and Paid up capital of N85million (Olaitan 2006:3). The capital base of the fund was increased to N3billion in March 2001.The CBN handles the day-to-day operations of the fund through its Development Finance Departments/Offices in all the states of the federation and is responsible to the board of the fund. The fund guarantees credit facilities extended to farmers (for approved agricultural projects) by banks up to $75 \%$ of the amount in default net the amount realized from the security pledged by the borrower.

Between 1978 and 1989 when the government stipulated lending quotas for banks under the scheme, there was consistent increase in the lending portfolios of banks to agriculture (table 2), but after the deregulation of the financial system, banks started reducing their loans to the sector due to the perceived risk. For instance, the amount of loan guaranteed under the fund dropped below N100 million from 1990 till 1993. In order to reverse the declining trend, certain incentives and palliatives, such as the Interest Draw Back (IDB) programme, the Trust Fund Model and Self-Help Group Linkage Banking were introduced (CBN 2013). Interest rate under the ACGSF is market determined, but as earlier noted, the CBN offers a rebate equivalent to $40 \%$ of the loan interest when loans are fully repaid on schedule. The scheme deals mainly with small farmers who need small loan to operate (Eze 2010: 6). But there are also big borrowers under the ACGSF.

\section{ii. Commercial Agriculture Credit Scheme (CACS), (2009 to date)}

As part of its developmental role, the $\mathrm{CBN}$ in collaboration with the Federal Ministry of agriculture and Water Resources (FMA\&WR) in 2009 established the CACS to provide finance for the country's agricultural value chain (production, processing, storage and marketing). The primary objectives of the scheme are to:

(a) Fast track the development of the agricultural sector by providing credit facilities to large-scale commercial farmers at a single digit interest rate;

(b) Enhance food security by increasing food supply, thereby promoting low food inflation;

(c) Reduce the cost of credit in agricultural production to enable farmers exploit the untapped potentials of the sector; and

(d) Increase output, generate employment, diversify Nigeria's revenue base, raise the level of foreign exchange earnings and provide input for manufacturing and processing on a sustainable basis.

The CACS which is a sub-component of the Federal Government of Nigeria's Commercial Agriculture Development Scheme (CADP) is financed through a N200 billion Bond raised through the Debt Management Office (DMO). Loans under the CACS are disbursed at a maximum interest of $9 \%$. The subsidy arising from the divergence between the stipulated rate and the market rate on all loans granted, and the administrative expenses of the scheme are borne by the CBN. The day-to-day implementation of the scheme is carried out by a Technical Implementation Committee (TIC) made up of the director of the Development Finance Department of the $\mathrm{CBN}$ as the chairman, head of the agricultural credit support division of the CBN, and a consulting Group as members; and the programme coordinator of the commercial Agriculture Development Programme of the 
Federal Government as the Secretary. The first tranche of the scheme ran from May to December, 2009 while the second tranche commenced in February, 2010 and is still ongoing.

\section{CACS Performance by Value Chain}

A March, 2012 report by the CBN on the activities of the N200 billion CACS shows that the scheme have financed a total of 193 private sector and 29 state sponsored projects. Out of the 193 private sector sponsored projects, production accounted for $47 \%$ and dominated the activities funded while processing accounted for $39 \%$. Table 3 indicates a further disaggregation of CACS financed projects by Value Chain.

Table 3: Analysis of CACS Financed Projects by Value Chain

\begin{tabular}{|l|l|l|}
\hline Category & Number of Projects(\% of Projects) & Value (N'billions and \%) \\
\hline $\begin{array}{l}\text { Input } \\
\text { Supplies }\end{array}$ & $1(1 \%)$ & $1.7(1 \%)$ \\
\hline Production & $90(47 \%)$ & $45.6(32 \%)$ \\
\hline Processing & $76(39 \%)$ & $73.99(52 \%)$ \\
\hline Marketing & $16(8 \%)$ & $15.31(11 \%)$ \\
\hline & $10(5 \%)$ & $5.9(4 \%)$ \\
Storage & $\mathbf{1 9 3}$ & $\mathbf{1 4 2 . 5 3}$ \\
\hline Total &
\end{tabular}

The CBN (2012:16) report on its real sector interventions in Nigeria show that the CACS has impacted the economy in the following areas:

(a) over 38,711 new jobs has been created;

(b) 10 new oil palm processing companies producing $368,188 \mathrm{mt}$ of refined oil per annum was established;

(c) over $10 \%$ of national rice demand are produced by CACS beneficiaries; and

(d) through the scheme, the Savannah Sugar Company Ltd Numan Adamawa State has raised Sugar Cane output from 40,000 to 50,000 metric tons.

Whether or not these strides suffice for the target set for the CACS is debatable. Other schemes include the Refinancing and Rediscounting Facility, 2006 till date; Large Scale Agricultural Credit Scheme, 2009; and the supervised agricultural Loan Board.

\section{iii. N50 billion Agricultural Credit Support Scheme (ACSS), (2006 till date)}

The ACSS is an initiative of the Federal Government and the Central Bank of Nigeria with the active support and participation of the Bankers' committee. The initial ACSS fund of N50billion was established with contributions from the CBN and deposit money banks for the financing of large agricultural projects such as establishment or management of plantations, cultivation or production of crops and livestock. The borrowing rate is $14 \%$. But the CBN provide an interest subsidy of $6 \%$ while the borrower pays $8 \%$ at full repayment. The purpose of ACSS is to facilitate the development of the agricultural sector by advancing credit to farmers at low interest rates. By pursuing this strategy, the government hopes to exert downward pressure on prices of agricultural produce, especially food, leading to reduced inflation, increased export, diversification of government revenue base, and increased foreign exchange earnings (Eze et al 2010: 7). According to a CBN (2012: 11) report on its real sector interventions in Nigeria, ACSS since inception has paid a total of N872.55million as rebate to 43 projects.

\section{3 'Agricultural Programmes' for Providing Low-cost Credit to Farmers in Nigeria (i) National Poverty Eradication Programme (NAPEP), (1999 to date)}

Like FEAP, NAPEP was established by the federal government of Nigeria. The mode of operation is tailored towards directed (subsidized) credit to farmers. The programme consists of four schemes namely, Youth empowerment scheme which involves capacity acquisition, mandatory attachment, and credit delivery; Rural infrastructures Development scheme which involves the provision of portable water, rural electrification, transportation and communication development; Social welfare Services Scheme which is involved with qualitative education, primary health care, farmers empowerment and provision of social services, provision of agricultural input and credit delivery to rural farmers; and Natural Resources Development and Conservation Scheme which contains programmes for environmental protection through conservation of land and space, development of agricultural resources, solid minerals and waters resources. 
(ii) Rural Banking Programme (1977 to 1991)

Banks were encouraged to not only establish rural branches but also to extend at least 50 per cent of the deposit mobilized from the rural areas as loans and advances to rural dwellers. Defaulting banks were to be penalized.

\section{(iii) National FADAMA Development programme (1993 - date)}

This programme was aimed at increasing income of beneficiaries by at least $20 \%$. The programme was designed in 1993 to promote simple and low cost improved irrigation technology under World Bank financing. FADAMA is a Hausa word for low lying flood plains usually with easily accessible shallow groundwater. It is a major instrument for achieving the government's poverty reduction objective in rural areas of Nigeria. The beneficiaries are meant to come as a group known as FADAMA Community Association to the National FADAMA Development Programme. The programme empowers the association with resources, training, and technical assistance supports to properly manage and control the resources for their own development. FADAMA adopts a socially inclusive and participatory process in which all FADAMA users will collectively identify their development goals and pursue it when assisted. The programme is in its third phase currently due to its success in the States that first adopted it.

\section{(iv) Preferred Sector Allocation of Credit (1970 to 1996)}

Banks were mandated to extend 40 per cent of their loans and advances to agriculture which was designated a preferred sector. Banks that failed to meet this target were penalized. The funds not lent were transferred to the then Nigerian Agricultural and Cooperative Bank, NACB.

\subsection{Innovations and Initiatives by the CBN to Improve Lending Under its Agricultural Credit Policies}

To ensure that small farmers had the financial resources to widen their economic activities, the CBN initiated various models, products and strategies to improve lending under the Scheme. In specifics, these initiatives were introduced to either encourage lending bank to continue to lend to farmer and/or encourage farmer to repay the loans on schedule. Prominent among them are:

\section{(i). Self-Help Groups Linkage Banking Programme}

The Self-Help Groups Banking Linkage Programme (SHGBLP) for savings mobilization was launched under the ACGSF in 1991 and became operational in 1992. Under the programme, farmers with a common purpose are encouraged to form groups of between 5 and 15 people. They can then undertake regular savings, which are deposited in a partner bank of their choice. After saving for six months, they may then apply to the partner bank for a loan. The groups can be informal or registered (formal). Bank loans to a group are normally in multiples of the balance in their savings account at the time of loan application. Under this programme, a lending bank holds the group savings as security, which cannot be drawn on until loans are repaid. The aim of the Self-Help Groups Linkage Banking is to inculcate a culture of savings and banking in group members and for them to build up resources for financing their farm projects without recourse to bank borrowing in the long run. So far, banks have advanced loans nationwide four times the total balance in the savings accounts.

\section{(ii)Trust Fund Model (TFM)}

The Bank has widened the scope of Self-Help Groups Linkage Banking to include State Governments and blue chip companies willing to provide funds for farmers within their catchment areas or in the host communities where they operate. The intermediation is in the form of Trust Funds, which they deposit with partner lending banks to secure part of the banks' exposures to farmers. Companies participating in the TFM include the following:

(a) Micro Credit Scheme for Agricultural Development operated through the Shell Petroleum Development Company Ltd

(b) Green Card in association with Nigerian Agip Oil Company Ltd

(c) Total Oil Plc

State Governments participating in the TFM are Nassarawa, Ebonyi, Kogi, Benue, Lagos, Jigawa, Kwara and Katsina States. Katsina State Government raised a rural development loan from the International Fund for Agricultural Development and placed part of it with a partner lending bank to enable it to extend credit to farmers. In all the programmes, savings of the farmer groups were used to secure 25 per cent of the loans, the Trust Fund secures $25 \%$ while the ACGSF guarantees $75 \%$ of the balance. 
(iii) Interest Drawback Programme (IDP)

The IDP is a palliative introduced in 2004 to rebate interest to farmers who repay agricultural loans according to contractual terms. The IDP is designed to benefit farmers and entrepreneurs who borrow under the Agricultural Credit Guarantee Scheme. The current rebate is $40 \%$ of accrued interest. Farmers who fully repay their loans on time under the ACGS are refunded $40 \%$ of the interest on their agricultural loans.

Table 4: Value and Number of Claims Filed and Settle under the IDP of ACGSF

\begin{tabular}{|c|c|c|c|c|c|}
\hline \multirow[b]{2}{*}{ year } & \multicolumn{2}{|c|}{ Cum Claims Filed } & \multicolumn{2}{|c|}{ Claims Actually Settled } & \multirow{2}{*}{$\begin{array}{l}\text { Value of Unsettled } \\
\text { Claims (N'million) }\end{array}$} \\
\hline & Number & Value & Number & Value & \\
\hline 2004 & 774 & $4,552,029$ & 774 & $4,552,029$ & 0 \\
\hline 2005 & 9455 & $33,204,930$ & 8681 & $28,652,901$ & $4,552,029$ \\
\hline 2006 & 25251 & $81,930,151$ & 15796 & $48,725,220$ & $33,204,931$ \\
\hline 2007 & 46027 & $172,248,266$ & 20776 & $90,318,114$ & $81,930,152$ \\
\hline 2008 & 77176 & $312,740,809$ & 31149 & $140,492,542$ & $172,248,267$ \\
\hline 2009 & 92721 & $424,313,445$ & 15545 & $11,572,636$ & $412,740,809$ \\
\hline 2010 & 119137 & $632,768,875$ & 26416 & $208,455,429$ & $424,313,446$ \\
\hline April, 2011 & 129007 & $701,655,141$ & 9870 & $68,886,265$ & $632,768,876$ \\
\hline
\end{tabular}

Source: Study

As is clear from table 4, the number and value of claims paid to benefiting customers has been on the ascendency. But a more perceptive review of the pattern of claims filed and settled indicates that the value of unsettled claims have consistently been increasing since the inception of the IDP in 2004; suggesting poor performance of the IDP in term of providing incentives to farmers.

\section{Performance of Major Agricultural Credit policies and Agriculture in Nigeria's History}

\subsection{Performance of the ACGSF}

Earlier sections of this paper have highlighted several efforts made by the government of Nigeria through its various agencies to deepen investment in the agricultural sector as well as encourage small stake farmers to continue in agriculture. Apart from capacity building, a lot has been done to provide credit to the agricultural sector. It is, therefore, important to assess how the encouragement of the sector impacted on the overall growth and productivity of the sector. This section of the paper will, thus, take an empirical assessment of the performance of major agricultural credit policies and, generally, the growth of agricultural production in the country's history

\section{(i.) Default Claims Filed by Commercial Banks and Settled by CBN}

The CBN in its role as the managing agent of the ACGSF investigates the status of the default claims submitted by the lending banks and makes appropriate recommendations to the Board of the ACGSF for settlement. Claims settlement is central to the sustenance of the ACGS, in that Banks look forward to the payment of the $75 \%$ of the amount in default net the amount realized from the security pledged by the borrower as enshrined in the ACGSF guidelines (ACGSF guidelines, 2013). More importantly, the number and amount of loans filed in by the lending banks is a veritable pointer to the performance of agricultural loan granted under the scheme. A rising profile of the amount and number of loan filed points to misapplication of the facility as farmers can only liquidate their loans when it has been properly utilized. Table 5 presents the number and amount of claims filed and settled as well as the percentage of the later against claims filed.

Table 5: Claims Filed by Lending Banks and Settled by CBN in Selected Range of Years

\begin{tabular}{|l|l|l|l|l|l|l|}
\hline period & \multicolumn{2}{l|}{$\begin{array}{l}\text { Cumulative } \\
\text { Claims Filled }\end{array}$} & \multicolumn{2}{l|}{$\begin{array}{l}\text { Cumulative Claims } \\
\text { Settled }\end{array}$} & $\begin{array}{l}\text { Cum. Claims Settled as a } \\
\text { \% of cum. Claims Filed }\end{array}$ \\
\hline & No. & $\begin{array}{l}\text { Amount } \\
\text { N=('000) }\end{array}$ & No. & $\begin{array}{l}\text { Amount } \\
\text { N=('000) }\end{array}$ & No. (\%) & $\begin{array}{l}\text { Amount } \\
(\%)\end{array}$ \\
\hline $1978-1996$ & 501 & 24712.5 & 153 & 820.2 & 30.54 & 3.32 \\
\hline $1978-1990$ & 1132 & 65084.6 & 372 & 2695.8 & 32.86 & 4.14 \\
\hline $1978-2005$ & 16478 & 1063718 & 8424 & 157841.7 & 51.12 & 14.83 \\
\hline $1978-2011$ & 20093 & 1528323 & 9236 & 242586 & 45.97 & 15.87 \\
\hline
\end{tabular}

Source: Computed by Authors 
Note: The data used for the calculations are obtained from the Development Finance Office of the CBN and presented in table 2 .

As is clear in table 5, from inception in 1978 to 2005, a total of 16,478 claims valued N1,063.72million were filed on the Fund. Out of these, 8,424 claims with a value of N157.841million, which represents $51.12 \%$ of the number and a paltry $14.83 \%$ of the value of the claims filed, were settled. Further, from 1978 to April 2011, a total of 20,093 claims valued N1528.3million were filed by the lending banks on the Fund. Out of these, 9,236 claims with a value of N242.586million, which represents $45.97 \%$ of the number and $15.87 \%$ of the value of the claims filed, were settled. A cumulative claims settlement rate of $15.87 \%$ is too poor and points to the enormity of basic underlying factor(s) militating against prompt and full settlement of claims and the need to find these factor(s) and subsequently tackle them forthrightly. It also indicates the failure of the barrage of similar policies, programmes, schemes, institution, palliatives and several other similar measures (that have been suggested in the literature and implemented by government) to offer solution to the problem of nonperforming agricultural loans in Nigeria.

A cursory look at the consolidated statistics in table 2 reveals the trend of activities from inception of the scheme. The trend is further buttressed in figure 1.

Figure 1: Spread of Default Claims Filed by Lending Banks and settled by CBN (1978-2011)



Source: Author.

Note: Figure 1 is based on data in table 2.

Figure 1 shows that there were gradual increases in claims filed from 1978 to 1989. This was the period when government stipulated lending quota to banks under the ACGSF which resulted in gradual growth in the amount of loan guaranteed (table 2). The introduction of the structural adjustment programme in 1986 and market liberalization in 1989/1990 (Olaitan 2006: 5) together with the removal of the lending quota in 1989 did not solve the problem of persistent increases in default claims filed. Instead, the amount of default claims filed took a bullish trend from 1990 to 1995, remained relatively stable from 1996 to 2003 and rose astronomically to its zenith in 2004. This led the CBN to introduce some palliative measures such as the Interest Drawback Programme (IDP) in 2004; and Self-Help Group Linkage Banking in 1991, and the Trust Fund Model earlier reviewed. Were these measures able to improve loan performance and farmers' loan repayment rate on a sustainable basis? The answer to this question forms the focus of the next sub-section.

\section{(ii.) Cumulative Loans Guaranteed to Farmer under ACGSF and Fully Repaid}

Table 6: Cumulative Loans Guaranteed to Farmer under ACGSF and Fully Repaid (1978-2011)

\begin{tabular}{|l|l|l|l|l|l|l|}
\hline & \multicolumn{2}{|l|}{$\begin{array}{l}\text { Total loan Guaranteed } \\
\text { (analyzed by size) }\end{array}$} & \multicolumn{2}{|l|}{$\begin{array}{l}\text { Total loan Fully repaid } \\
\text { (analyzed by state) }\end{array}$} & $\begin{array}{l}\text { Loan } \\
\text { Difference }\end{array}$ & $\begin{array}{l}\text { Loan } \\
\text { Repayment } \\
\text { Rate (\%) }\end{array}$ \\
\hline & No. & $\begin{array}{l}\text { Amount } \\
\text { N=('000) }\end{array}$ & no. & $\begin{array}{l}\text { Amount } \\
\text { N=('000) }\end{array}$ & $\begin{array}{l}\text { Amount } \\
\text { N=('000) }\end{array}$ & \\
\hline $1978-2000$ & 293105 & $\mathbf{2 , 4 5 5 , 9 0 6 . 9 0}$ & 192312 & $\mathbf{1 4 2 0 7 1 8 . 5}$ & 1035188.4 & 57.85 \\
\hline 2001 & 20,298 & $\mathbf{7 2 8 , 5 4 5 . 4 0}$ & 19357 & $\mathbf{4 1 4 4 5 2 . 7}$ & 314092.7 & 56.89 \\
\hline 2002 & 23,681 & $\mathbf{1 , 0 5 1 , 5 8 9 . 8 0}$ & 18575 & $\mathbf{6 2 0 8 8 1 . 7}$ & 430708.1 & 59.04 \\
\hline
\end{tabular}


Matching Credit With Season: An Issue for Non Performing Agricultural Loans in Nigeria

\begin{tabular}{|l|l|l|l|l|l|l|}
\hline 2003 & 24,303 & $\mathbf{1 , 1 6 4 , 4 6 0 . 4 0}$ & 21652 & $\mathbf{9 1 0 1 8 1 . 2}$ & 254279.2 & 78.16 \\
\hline 2004 & 35,035 & $\mathbf{2 , 0 8 3 , 7 4 4 . 7 0}$ & 26208 & $\mathbf{1 1 7 1 7 5 4 . 2}$ & 911990.5 & 56.23 \\
\hline 2005 & 46,238 & $\mathbf{3 , 0 4 6 , 7 3 8 . 5 0}$ & 32549 & $\mathbf{1 8 6 1 0 9 7 . 1}$ & 1185641.4 & 61.08 \\
\hline 2006 & 54,032 & $\mathbf{4 , 2 6 3 , 0 6 0 . 3 0}$ & 30808 & $\mathbf{2 0 5 6 6 0 1 . 7 5}$ & 2206458.55 & 48.24 \\
\hline 2007 & 43,233 & $\mathbf{4 , 4 2 5 , 8 6 1 . 8 4}$ & 35794 & $\mathbf{2 8 6 0 7 2 3 . 5 1}$ & 1565138.33 & 64.64 \\
\hline 2008 & 52,787 & $\mathbf{6 , 7 2 1 , 0 7 4 . 5 6}$ & 31,171 & $\mathbf{3 0 6 7 5 8 5 . 3 9}$ & 3653489.17 & 45.64 \\
\hline 2009 & 53,639 & $\mathbf{8 , 3 4 9 , 5 0 9 . 2 8}$ & 34300 & $\mathbf{3 6 2 1 3 9 4 . 9 3}$ & 4728114.35 & 43.4 \\
\hline 2010 & 50,849 & $\mathbf{7 , 7 4 0 , 5 0 7 . 6 3}$ & 50119 & $\mathbf{5 8 5 0 9 2 3 . 3 5}$ & 1889584.28 & 75.6 \\
\hline $\begin{array}{l}\text { April, } \\
2011\end{array}$ & 41,856 & $\mathbf{7 , 6 2 3 , 2 1 6 . 2 5}$ & 9382 & $\mathbf{1 3 7 5 7 9 6 . 5 8}$ & 6247419.67 & \\
\hline \multicolumn{1}{|l|}{} & 740,056 & $49,772,826.56$ & $\mathbf{5 0 2 , 2 2 7}$ & $\mathbf{2 5 , 4 2 5 , 4 1 5 . 9 5}$ & $24,347,411$ & AVE=51.1\% \\
\hline
\end{tabular}

Source: Development Finance Department/Office, CBN; Figures for 1978-2000 are aggregated by the Author.

Table 6 shows that ACGSF has made impressive strides in terms of loan guaranteed but performed abysmally in the area of loan repayment. From inception in 1978 to April 2011, the Fund has guaranteed a total of 740,056 loans valued at $\mathrm{N} 49$.8billion out of which $\mathrm{N} 25.43$ billion were fully repaid. This represents a loan difference of N24.3billion and a repayment rate of $51.1 \%$ over the period. This further translates into a loan default rate of about $49 \%$. A loan repayment rate of $51.1 \%$ shows an unsustainable loan repayment profile for the ACGSF. This is further buttressed by the widening spread (gap) between the loan guaranteed and fully repaid under the scheme over the period under analysis (figure 2). This explains the unwillingness of many commercial banks to finance agriculture despite guarantees provided by the government. If loans are disbursed to farmers to align with agricultural season in Nigeria (figure 4), it will ensure optimal deployment and utilization of the fund in line with various stages of agricultural activities (figure 5). The tendency is that more farmers will repay their loan in order to garner the benefits accruable from various incentives and palliatives put in place by the government through its agencies. This would engender a reduction in loan default rate. The fact that farmers are generally unable to pay back the loans despite barrage of government policies and incentives implemented over the years points to the fact that the root cause of non-performing agricultural loan is yet to be addressed.

Figure 2: Spread of Loan Guaranteed under ACGSF and Loan Fully Repaid by Farmers (2001-2011)

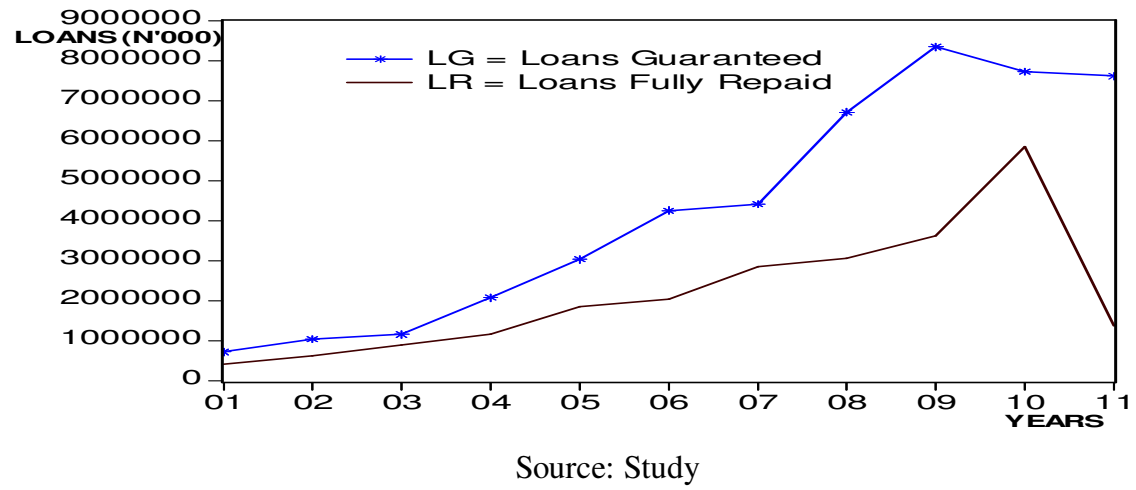

Note: Data used for figure 2 were obtained from the Development Finance Office, CBN.

\subsection{Performance of Agriculture in Nigeria}

Quite a lot has been discussed about funding of agriculture in this paper. Before we proceed to present our suggestion to strengthen the sector, it is important that we seek to know how the country's agricultural sector is currently performing. We will, therefore, examine budget allocation to the sector and its performance in terms of productivity and contribution to GDP, among others.

\section{(i). The Agricultural Sector's Budget Structure in Nigeria}


Public expenditure on agriculture which serves as the bedrock of financing for the sector has consistently fallen short of recommendations. In fact, the process of budgeting in Nigeria can be said to be detrimental, not only to agriculture, but to overall real growth and productive development. Over the past 10 years (2002-2011), federal and state budgets have consistently been structured in such a manner that the recurrent expenditure (non-productive expenditure, including overheads, wages, emoluments, etc) have been allocated more than $65 \%$ of the total budget while less than $35 \%$ of the budget have been allocated to capital projects (the basis for infrastructural development and job creation, among others). This is glaring from table 1 where the share of capital expenditure in total federal budget has been less than $35 \%$ for most part of the civilian regime in Nigeria's fourth republic.

Again, since 2000, public spending on agriculture has been less than $2 \%$ of the federal budget except in 2008 when a paltry $2.02 \%$ of the total budget was allocated to agriculture (see figure 3 ; table 1). This had been corroborated by the Nigeria Agricultural Public Expenditure Review, a collaborative study carried out by the International Food Policy Research Institute (IFPRI) and the World Bank. The 2\% share of agriculture in total federal budget is below the $10 \%$ goal set by African leaders under the Comprehensive Africa Agricultural Development Programme, CAADP, in Maputo Mozambique (Maputo declaration 2003) and far below the $25 \%$ target set by the UN Food and Agricultural Organization, FAO (Iganga and Umenhilin, 2011:83). The CAADP was established by the AU assembly in 2003 with focus on improving food security, nutrition, and increasing incomes in African farming economies. It aims to achieve this by raising agricultural productivity by at least $6 \%$ per year and increasing public investment in agriculture to $10 \%$ of national budget per year.

Figure 3: Share of Agricultural Expenditure in Total Expenditure:

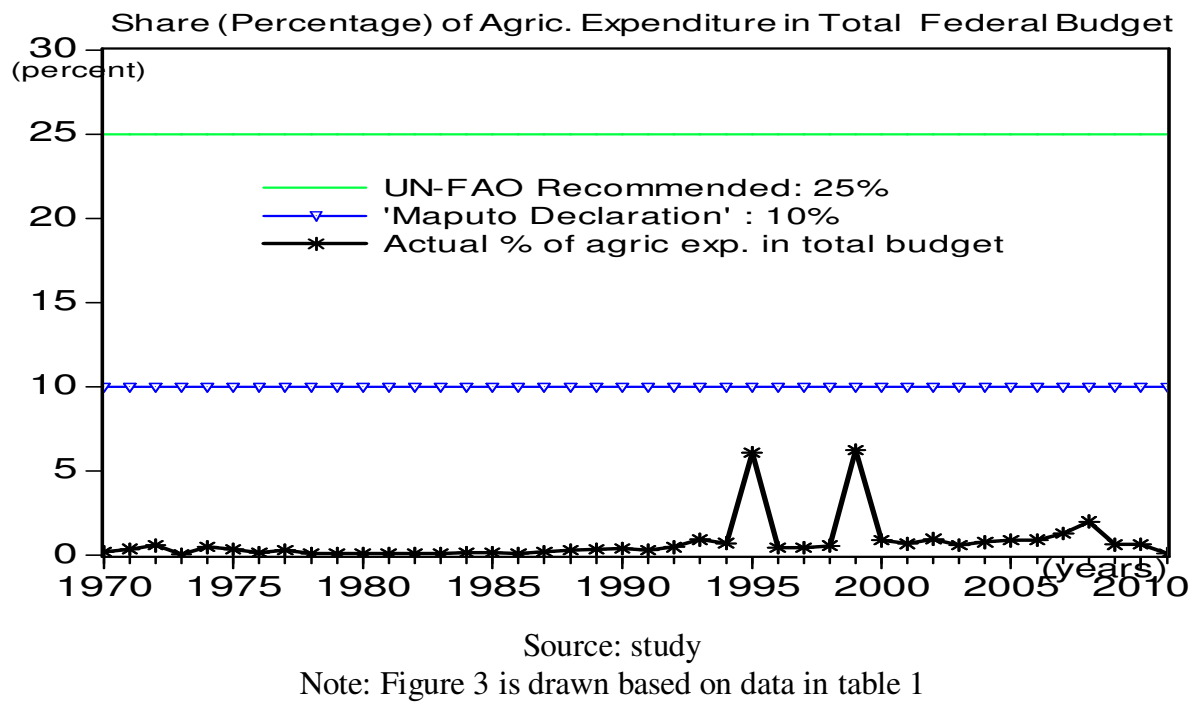

From figure 3, the share of agriculture in total budget grossly falls short of the recommended level. It clearly shows that Nigerian's agriculture is abysmally underfinanced. It is therefore not surprising that agricultural policies have failed to achieve the desired goals of food self-sufficiency, self-reliance, poverty reduction and rural development.

Table 7 shows the composition of government expenditure in Sub-Sahara Africa and other low-and middle-income countries. It indicates that Sub-Sahara African states have spent least on agriculture (than South Asia, Middle East and North Africa, East Asia and the Pacific) relative to other sectors of the economy. In SubSahara Africa, it is glaring that not only have the economies spent least on agriculture and health, the share of agriculture in total expenditure has also been declining. This is supportive of the poor profile of agricultural expenditure in Nigeria.

Table 7: Composition of Government Expenditures by Sectors and Region in Selected low- and Middle-income countries

\begin{tabular}{|l|l|l|l|l|l|}
\hline Region & Year & $\begin{array}{l}\text { Agric } \\
(\boldsymbol{\%})\end{array}$ & Defence(\%) & Education (\%) & $\begin{array}{l}\text { Health } \\
(\%)\end{array}$ \\
\hline $\begin{array}{l}\text { East Asia and the } \\
\text { Pacific (8) }\end{array}$ & 1980 & 11.1 & 15.8 & 10.5 & 5.6 \\
\hline
\end{tabular}


Matching Credit With Season: An Issue for Non Performing Agricultural Loans in Nigeria

\begin{tabular}{|l|l|l|l|l|l|} 
& 2000 & 6.9 & 6.9 & 16.4 & 6.2 \\
\hline Middle east and & 2007 & 6.5 & 7.2 & 13.8 & 4.2 \\
North Africa (7) & 1980 & 4.5 & 17.5 & 15.6 & 4.5 \\
& 1990 & 4.9 & 13.3 & 18.7 & 9 \\
& 2000 & 4.4 & 15.1 & 14.8 & 10.5 \\
\hline South Asia (7) & 2007 & 3.1 & 10.5 & 11.8 & 7.7 \\
& 1980 & 6.6 & 19.2 & 2.9 & 2 \\
& 1990 & 6.9 & 18.1 & 3.1 & 1.8 \\
\hline Sub-Sahara Africa & 2000 & 4.8 & 15.3 & 3.4 & 1.8 \\
(10) & 2007 & 4.9 & 12.9 & 4.6 & 2.3 \\
& 1980 & 6 & 6.1 & 11.9 & 3.4 \\
& 1990 & 6 & 8.4 & 13.9 & 4.7 \\
& 2000 & 3.6 & 6.1 & 15.5 & 7.3 \\
\hline
\end{tabular}

Source: Adapted from Food and Agricultural Organization (2012:28)

Note: Calculations include 32 low- and middle-income countries. The number of countries included in each group is shown in parenthesis. Computation is based on IFPRI, 2010.

\section{(ii) Agricultural Productivity and Share of AgriculturalOutput in total GDP}

Agricultural productivity is defined as the ratio of physical output such as kilograms or tons of crop produced to the number of hectares of land used (efficiency of land productivity) or total man hours employed (agricultural labour productivity). Thus productivity in the agricultural sector can be analyzed in terms of the total yield from the four major sub-sectors, namely, crops, livestock, fishery and forestry. In a World Bank report published in 2012, Cereal yield ( $\mathrm{kg}$ per hectare) in Nigeria was last reported at 1,413 tons per hectare in 2010. The Cereals includes wheat, rice, maize, barley, oats, rye, millet, sorghum, buckwheat, and mixed grains. Production data on cereals relate to crops harvested for dry grain only. Cereal crops harvested for hay or harvested green for food, feed, or silage and those used for grazing are excluded. As figure 4 shows, over the past 30 years, this indicator reached a maximum value of 1,655.40 in 1981 and a minimum value of 1094 in 1991. In the World Bank (2012) report, productivity in Nigeria's agricultural sector was shown to have been very low. This has been corroborated by the present government's confirmation that the poor Nigeria's agricultural production output is an unacceptable situation that has to be changed. According to Vice President Mohammed Namadi Sambo

"It's unfortunate that, it's only in Nigeria that the average production is 1.3 tons per hectare when there are neighboring countries in Africa with an average production of 8 tons per hectare. This is unacceptable and we plan to change it." (Peoples' Daily Newspaper, March 29, 2012)

Figure 4: Agricultural Productivity - Cereal Yield (kg per hectare) in Nigeria

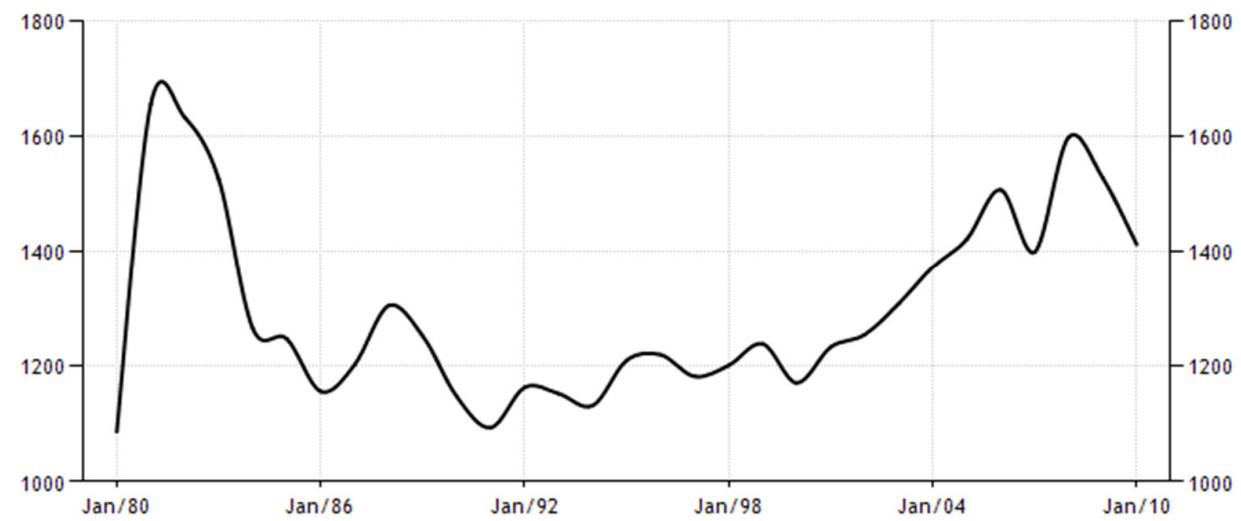

Source: World Bank report, 2012.

Statistics from the National Bureau of Statistics (2012), indicates that agriculture has contributed more to the national GDP than oil and gas and has thus remained a significant component of the national economy, employing over $60 \%$ of Nigeria's 150 million people. From table 1, the share of agricultural output in total output (GDP) were $32.7 \%$ in $2007 ; 32.9 \%$ in $2008 ; 37 \%$ in $2009 ; 30 \%$ in 2010 ; and $30.9 \%$ in 2011 . Yet the sector has remained substantially small scaled (with respect to output rather than cultivated acreage) attracting 
very little investment. Thus, it can be seen that the modest contribution of agriculture to GDP has resulted from rising cultivated acreage rather than rise in productivity in the sector.

\section{The Conceptual Framework - Seasonality Model}

\subsection{Background}

Literature is replete with the failure of policies to adequately address agricultural intensification in Nigeria. Many experts have suggested several causes as being responsible for non-performance of agricultural loans and the huge rate of default. Such highlighted suggestions have been adopted by government in recent and roll-over programmes to test effectiveness of research and suggestions, but the problem has not been addressed. The sector is still sluggish; loans are not performing as repayment rate is still low; agricultural productivity is still low and banks are averse to granting loans to the sector. These informed our interest to search further so as to unearth the variable(s) that had perpetuated the present sluggish situation. While analyzing loans and disbursement to agricultural sector, we discovered from the disbursement flow that a serious mismatch was committed. Loans were paid out to farmers arbitrarily without matching with farming seasons. This provided the basis for the model suggested to solve the problem of non-performing agricultural loans in Nigeria, the Seasonality Model.

A situation where commercial banks' loan decisions are tied to government's fiscal activities, as well as, CBN's monetary decisions, made loans to agricultural sector to be restricted to economy-wide fiscal and monetary decision structure. Commercial banks will, for instance, wait for government budget and CBN monetary policy guidelines before deciding on loans to beneficiaries. The purposes for which loans are to be disbursed are scarcely considered in the decision taking space. In many occasions, Nigerian government will not bring out its budget until mid-year. The CBN will also depend on the 'spirit' of the budget to decide its monetary policy direction. Deducing further it can be noticed clearly that based on current practice of institutions mentioned above, loans will not get to farmers until, perhaps mid-year, when farming had already begun. The seasonality model highlights the importance of credit alignment with agricultural seasons in Nigeria.

\subsection{Seasonality Model}

The seasonality model indicates the various agricultural seasons in Nigeria, how agriculture is intensified in these seasons and how necessary it would be for lending banks to align credit disbursement with these seasons. Nigeria has two major seasons, Dry Season and Rainy season. Some parts of the dry season is dry, windy and dusty (the harmattan). This season covers the period from October to March and also the month of August, which is referred to as the 'August break'. Notably, in the twelve months period of a year, the dry season, which is very inclement for agriculture, takes seven months. Figure 5 presents agricultural season that is typical of Nigeria.

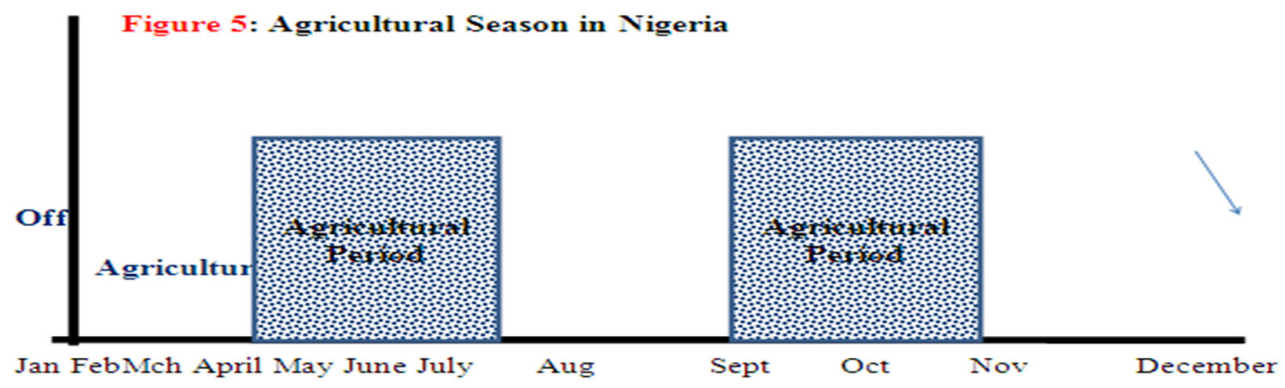

Source: Study

As shown in figure 5, the wet or rainy season starts in April effectively, recedes in July and continues in September. This season ushers in rain for purposes of agriculture and it covers a period of five months only.

For agricultural investors, particularly farmers, they need to undertake the following processes before they commence cultivation:

(a) Land Preparation - In traditional and subsistence agriculture as mostly practiced in Nigeria, this period is mostly used for land preparation. This include bush cutting, burning, and in some cases tilling and application of manure. 
(b) Looking for seedlings - While preparing the land, many farmers go on to acquire seedlings that will be used in the farms. Such seedlings are sourced and prepared prior to planting after land preparation and after the early rains.

(c) Building farm settlements - In instances where farms are far away from community settlements, temporary farm huts and settlements are constructed during land preparation. This is to provide temporary shelter and settlement for farm workers. In many cases farmers migrate to live in these settlements during the full farming seasons.

(d) Arranging for purchasing of farm implement and equipment - Purchase and acquisition of farm implements come before and during land preparation stages. Hoes, matches, diggers, storage barns, etc., are all purchased for use in the stage of farm preparation.

All of these include things that the farmer will do in the preparatory stages. Planting of farm products or agricultural cultivation in Nigeria is done mostly in the wet or rainy season. This is because the farmers need quite a quantity of water to irrigate their farms. And since Dams are too costly to be constructed by these farmers, they resort to planting in the rainy season. This means that farmers have only between April and September, excluding, even August, to cultivate their farm. For any farmer to expect good harvest in the dry season or harvest period, all preparations for planting must be completed before the start of cultivation (implementation). Anything short of this will mean that the farmer will be late and may even postpone cultivation for the season. Figure 6 shows the various stages in agricultural practice in the country.

Figure 6: Stages in Agricultural Practices (activities) in Nigeria

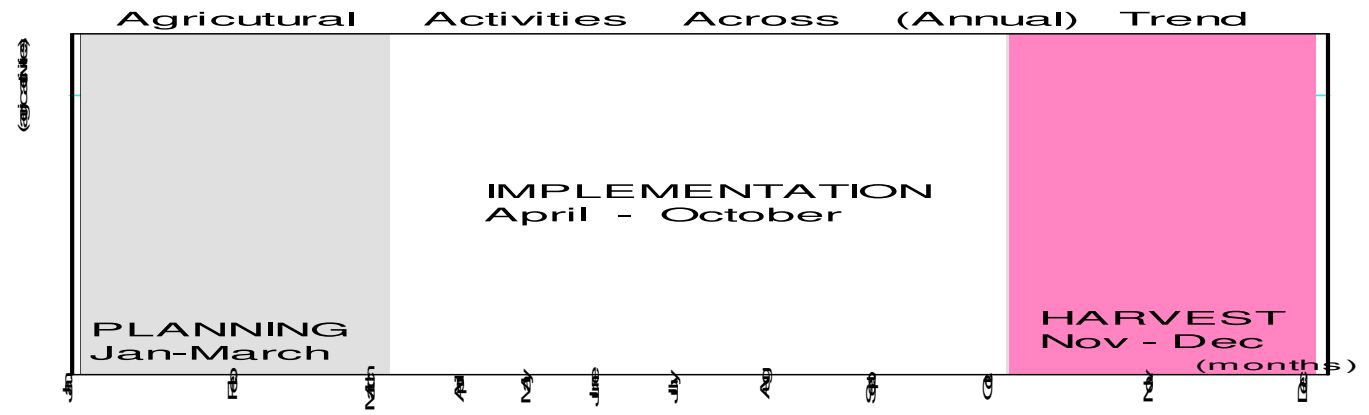

Source: Study

As is clear from the foregoing presentations, agricultural loans expected by farmers are, therefore, for purposes of activating the farming process from the planning to implementation and even harvest stages. If any of these stages are skipped, there is a tendency for 'farming failure'. It therefore implies that if farmers expect to have good and better yield, they have to pass through the three stages in their production process. If they require credit to do this, lending banks must disburse the credit to farmers prior to the commencement of activities in stage 1 . If loans are disbursed to farmers after the activities in stage 1 had commenced, then farmers would miss activities in Stage 1, a prerequisite for Stages 2 and 3, which also remains very key in the production process.

So, when are credits disbursed to the farmers? Do Banks consider the seasons while granting agricultural loans? Lending banks in Nigeria tend to take credit decisions without any relation to the complexity of the farming season. They bundle agricultural credit into the bunch of other credit sectors of the economy. They do not disaggregate to see when, why, and where agricultural credit is extended. In many cases banks in Nigeria start their banking year in the preparatory period for farming. It is also interesting to note that government fiscal budget also start in that early period of the year. In most cases, bank credit goes to farmers at harvest seasons (Stage 3), while in other cases it goes to them sometimes in Stage 2. If this happens, there is a tendency for the farmer to misapply the credit. Alternatively, the farmer may want to try rushing and/or mixing activities of the various stages to apply the credit. The result of either or both of these scenarios is inevitable; the misapplication of the loan facility, poor harvest, and high default rate. All of these translate to poor performance of agricultural loan.

\subsection{Summary of Major Findings}

\section{Summary Of Major Findings And policy Implications}

The findings from this study indicate that ACGSF made impressive strides in terms of the number and amount of loan guaranteed but performed abysmally in the area of loan repayment. A loan repayment rate of $51.1 \%$ which implies a default rate of about $49 \%$ points to an unsustainable loan repayment profile for the ACGSF. This explains the unwillingness of many commercial banks to finance agriculture despite guarantees 
provided by the government.That farmers are generally unable to repay the loans despite the barrage of government policies, incentives and palliatives implemented over the years point to the fact that the root cause of non-performing agricultural loan is yet to be addressed. From the disbursement flow of the loans, it was discovered that a serious mismatch was committed as loans were paid out to farmers arbitrarily without matching with farming seasons. The divergence between the period loans are disbursed to farmers and the commencement of agricultural activities manifest in misapplication and poor loan performance.

There is also the problem of poor settlement of claims filed under the ACGSF and its IDP. While the rising trend of unsettled claims under the ACGSF discourages banks from lending to agriculture, poor settlement of claims under the IDP serves to discourage farmers from repaying their loans on schedule, or worse still, discourage them from applying for loans under the scheme. A cumulative claims settlement rate of $15.87 \%$ under the ACGSF is too poor and, again, indicates the enormity of basic underlying factor(s) militating against prompt and full settlement of claims.

Qualified evidence from the study has also shown that the process of budgeting in Nigeria is detrimental, not only to agriculture, but to overall real growth and productive development. Over the past 10 years (2002-2011), 65\% of the total budget have been allocated to recurrent expenditure (unproductive expenditure) while less than $35 \%$ of the budget have been allocated to capital projects (the basis for infrastructural development and job creation, among others). This poor and unproductive budget structure has been made worse by poor funding of the Nigeria's agricultural sector. In fact, agriculture has been abysmally underfunded with the share of agricultural expenditure in total federal budget (expenditure) averaging a paltry $0.81 \%$ over the past decade (2001-2011), (see table 1 ). The $0.81 \%$ share of agriculture in total federal budget is below the $10 \%$ goal set by African leaders under the Comprehensive Africa Agricultural Development Programme, CAADP, in Maputo Mozambique (Maputo declaration 2003) and far below the 25\% target set by the UN Food and Agricultural Organization, FAO. The study further shows that agriculture has contributed more to the national GDP than oil and gas and has thus remained a significant component of the national economy, employing over $60 \%$ of Nigeria's 150 million people. The sector has, however, remained substantially small scaled (with respect to output rather than cultivated acreage) attracting very little investment.

\subsection{Implication of Findings for Policy}

Loan default in agriculture is an enormous problem as it is a major contributor to the persistent poor performance of Nigerian agricultural sector. It serves to reduce the amount of loan accommodation extended to agriculture because of the perceived risk of default in payment. Consequently, agricultural production is harmstrung by inadequacy of circulating capital. This tends to perpetuate the vicious cycle of poverty characterizing the small-holder farmers who constitute over $70 \%$ of the Nigerian populace.

Granted that Nigeria's agricultural sector is abysmally underfunded and the general pattern of federal budget detrimental to agricultural productivity and overall real growth, why have the barrage of policies and incentives to provide cheap loans to the sector continued to fail? Evidently, the mismatch of credit disbursement with seasons attenuated growth and productivity of agriculture in Nigeria, resulting in poor loan performance. This manifests in high loan delinquency and default rate. This is the nitty-gritty of non-performing agricultural loan in Nigeria.

An innovative strategy capable of solving the problem of default in agricultural financing and as such aiding the process of enhanced agricultural productivity and national development is the Seasonality Model (SM) suggested in this paper

\section{APENDICES 1}

Table 1: Share of Agricultural expenditure in Total Federal Budget, share of Capital Expenditure in total expenditure, and Contribution of Agriculture to Gross Domestic Product (19702011), N'million

\begin{tabular}{|c|c|c|c|c|c|c|c|c|c|}
\hline $\begin{array}{l}\text { YEA } \\
R\end{array}$ & $\mathrm{RE}(\mathrm{N}$ 'm & $\begin{array}{l}\text { CE } \\
\left(N^{\prime} m\right)\end{array}$ & $\begin{array}{l}\text { Total } \\
\text { Budget }\end{array}$ & $\begin{array}{l}\text { Tot. } \\
\text { Exp. } \\
\text { On } \\
\text { Agric }\end{array}$ & $\begin{array}{l}\% \text { of } \\
\text { AgricExp } \\
\text { in Tot. } \\
\text { Budget }\end{array}$ & $\begin{array}{l}\text { Agric } \\
\text { Output } \\
\left(N^{\prime} m\right)\end{array}$ & $\begin{array}{ll}\text { GDP } \\
\text { Curr. } \\
\text { Basic } \\
\text { Prices } \\
\left(N^{\prime} m\right) \\
\end{array}$ & $\begin{array}{l}\% \text { Of } \\
\text { Agric } \\
\text { Outpu } \\
\mathrm{t} \text { in } \\
\text { GDP }\end{array}$ & SCTE \\
\hline 1970 & 716.10 & 187.80 & 903.9 & 1.92 & 0.21 & $2,576.40$ & $5,281.10$ & 48.8 & 20.77 \\
\hline 1971 & 823.60 & 173.60 & 997.2 & 3.86 & 0.38 & $3,033.70$ & $6,650.90$ & 45.61 & 17.40 \\
\hline 1972 & $1,012.30$ & 451.30 & 1463.6 & 8.89 & 0.6 & $3,092.70$ & $7,187.50$ & 43.03 & 30.83 \\
\hline 1973 & 963.50 & 569.70 & 1529.2 & 10.75 & 0.07 & $3,261.20$ & $8,630.50$ & 37.79 & 37.25 \\
\hline 1974 & $1,517.10$ & $\begin{array}{l}1,223.5 \\
0\end{array}$ & 2740.6 & 13.77 & 0.502 & $4,377.90$ & $18,823.10$ & 23.2 & 44.64 \\
\hline 1975 & $2,734.90$ & $3,202.7$ & 5942.6 & 22.43 & 0.377 & $5,872.92$ & $21,475.24$ & 27.34 & 53.89 \\
\hline
\end{tabular}


Matching Credit With Season: An Issue for Non Performing Agricultural Loans in Nigeria

\begin{tabular}{|c|c|c|c|c|c|c|c|c|c|}
\hline & & 0 & & & & & & & \\
\hline 1976 & $3,815.40$ & $\begin{array}{l}4,041.3 \\
0\end{array}$ & 7856.7 & 11.71 & 0.149 & $6,121.96$ & $26,655.78$ & 22.9 & 51.4 \\
\hline 1977 & $3,819.20$ & $\begin{array}{l}5,004.6 \\
0\end{array}$ & 8823.8 & 29.38 & 0.332 & $7,401.64$ & $31,520.34$ & 23.48 & 56.7 \\
\hline 1978 & $2,800.00$ & $\begin{array}{l}5,200.0 \\
0\end{array}$ & 8000 & 8.69 & 0.108 & $8,033.55$ & $34,540.10$ & 23.2 & 65 \\
\hline 1979 & $3,187.20$ & $\begin{array}{l}4,219.5 \\
0\end{array}$ & 7400.7 & 9.15 & 0.123 & $9,213.14$ & $41,974.70$ & 21.9 & 57.01 \\
\hline 1980 & $4,805.20$ & $\begin{array}{l}10,163 . \\
30\end{array}$ & 14968.5 & 17.14 & 0.114 & $10,011.46$ & $49,632.32$ & 20.1 & 67.89 \\
\hline 1981 & $4,846.70$ & $\begin{array}{l}6,567.0 \\
0\end{array}$ & 11413.7 & 13.03 & 0.114 & $13,580.32$ & $47,619.66$ & 28.5 & 57.53 \\
\hline 1982 & $5,506.00$ & $\begin{array}{l}6,417.2 \\
0\end{array}$ & 11923.2 & 14.80 & 0.124 & $15,905.50$ & $49,069.28$ & 32.4 & 53.82 \\
\hline 1983 & $4,750.80$ & $\begin{array}{l}4,885.7 \\
0\end{array}$ & 9636.5 & 12.77 & 0.132 & $18,837.19$ & $53,107.38$ & 35.47 & 50.6 \\
\hline 1984 & $5,827.50$ & $\begin{array}{l}4,100.1 \\
0\end{array}$ & 9927.6 & 15.66 & 0.157 & $23,799.43$ & $59,622.53$ & 39.9 & 41.30 \\
\hline 1985 & $7,576.40$ & $\begin{array}{l}5,464.7 \\
0\end{array}$ & 13041.1 & 20.36 & 0.156 & $26,625.21$ & $67,908.55$ & 39.2 & 41.9 \\
\hline 1986 & $7,696.90$ & $\begin{array}{l}8,526.8 \\
0\end{array}$ & 16223.7 & 20.69 & 0.127 & $27,887.45$ & $69,146.99$ & 40.3 & 52.5 \\
\hline 1987 & $\begin{array}{l}15,646.2 \\
0\end{array}$ & $\begin{array}{l}6,372.5 \\
0\end{array}$ & 22078.7 & 46.15 & 0.209 & $39,204.22$ & $\begin{array}{l}105,222.8 \\
4\end{array}$ & 37.2 & 28.8 \\
\hline 1988 & $\begin{array}{l}19,409.4 \\
0\end{array}$ & $\begin{array}{l}8,340.1 \\
0\end{array}$ & 27749.5 & 83.00 & 0.299 & $57,924.38$ & $\begin{array}{l}139,085.3 \\
0\end{array}$ & 41.6 & 30.05 \\
\hline 1989 & $\begin{array}{l}25,994.2 \\
0 \\
\end{array}$ & $\begin{array}{l}15,034 . \\
10\end{array}$ & 41028.3 & $\begin{array}{l}151.8 \\
0 \\
\end{array}$ & 0.369 & $69,713.00$ & $\begin{array}{l}216,797.5 \\
4\end{array}$ & 32.1 & 36.6 \\
\hline 1990 & $\begin{array}{l}36,219.6 \\
0\end{array}$ & $\begin{array}{l}24,048 . \\
60\end{array}$ & 60268.2 & $\begin{array}{l}258.0 \\
0\end{array}$ & 0.428 & $84,344.61$ & $\begin{array}{l}267,549.9 \\
9\end{array}$ & 31.5 & 39.9 \\
\hline 1991 & $\begin{array}{l}38,243.5 \\
0\end{array}$ & $\begin{array}{l}28,340 . \\
90\end{array}$ & 66584.4 & $\begin{array}{l}208.7 \\
0\end{array}$ & 0.313 & $97,464.06$ & $\begin{array}{l}312,139.7 \\
4\end{array}$ & 31.2 & 42.5 \\
\hline 1992 & $\begin{array}{l}53,034.1 \\
0\end{array}$ & $\begin{array}{l}39,763 . \\
30\end{array}$ & 92797.4 & $\begin{array}{l}455.9 \\
7\end{array}$ & 0.491 & $145,225.25$ & $\begin{array}{l}532,613.8 \\
3\end{array}$ & 27.2 & 42.84 \\
\hline 1993 & $\begin{array}{l}136,727 . \\
10\end{array}$ & $\begin{array}{l}54,501 . \\
80\end{array}$ & 191229 & $\begin{array}{l}1,803 . \\
81\end{array}$ & 0.943 & $231,832.67$ & $\begin{array}{l}683,869.7 \\
9\end{array}$ & 33.9 & 28.50 \\
\hline 1994 & $\begin{array}{l}89,974.9 \\
0\end{array}$ & $\begin{array}{l}70,918 . \\
30\end{array}$ & 160893 & $\begin{array}{l}1,183 . \\
29\end{array}$ & 0.735 & $349,244.86$ & $\begin{array}{l}899,863.2 \\
2\end{array}$ & 38.8 & 44.07 \\
\hline 1995 & $\begin{array}{l}127,629 . \\
80\end{array}$ & $\begin{array}{l}121,13 \\
8.30 \\
\end{array}$ & 24768.1 & $\begin{array}{l}1,510 . \\
40\end{array}$ & 6.098 & $619,806.83$ & $\begin{array}{l}1,933,211 \\
.55\end{array}$ & 32.0 & 489.09 \\
\hline 1996 & $\begin{array}{l}124,491 . \\
30\end{array}$ & $\begin{array}{l}212,92 \\
6.30\end{array}$ & 337218 & $\begin{array}{l}1,592 . \\
56\end{array}$ & 0.472 & $841,457.07$ & $\begin{array}{l}2,702,719 \\
.13\end{array}$ & 31.13 & 63.14 \\
\hline 1997 & $\begin{array}{l}158,563 . \\
50\end{array}$ & $\begin{array}{l}269,65 \\
1.70\end{array}$ & 428215 & $\begin{array}{l}2,058 . \\
88\end{array}$ & 0.480 & $953,549.37$ & $\begin{array}{l}2,801,972 \\
.58\end{array}$ & 34.03 & 62.97 \\
\hline 1998 & $\begin{array}{l}178,097 . \\
80\end{array}$ & $\begin{array}{l}309,01 \\
5.60\end{array}$ & 487113 & $\begin{array}{l}2,891 . \\
70\end{array}$ & 0.593 & $\begin{array}{l}1,057,584 . \\
01\end{array}$ & $\begin{array}{l}2,708,430 \\
.86\end{array}$ & 39.04 & 63.43 \\
\hline 1999 & $\begin{array}{l}449,662 . \\
40\end{array}$ & $\begin{array}{l}498,02 \\
7.60\end{array}$ & 947690 & $\begin{array}{l}59,31 \\
6.17\end{array}$ & 6.259 & $\begin{array}{l}1,127,693 \\
12\end{array}$ & $\begin{array}{l}3,194,014 \\
.97\end{array}$ & 35.3 & 52.55 \\
\hline 2000 & $\begin{array}{l}461,600 . \\
00\end{array}$ & $\begin{array}{l}239,45 \\
0.90\end{array}$ & 701059 & $\begin{array}{l}6,335 . \\
78\end{array}$ & 0.903 & $\begin{array}{l}1,192,910 . \\
00\end{array}$ & $\begin{array}{l}4,582,127 \\
.29\end{array}$ & 26.03 & 34.15 \\
\hline 2001 & $\begin{array}{l}579,300 . \\
00\end{array}$ & $\begin{array}{l}438,69 \\
6.50\end{array}$ & 1018026 & $\begin{array}{l}7,064 . \\
55\end{array}$ & 0.693 & $\begin{array}{l}1,594,895 . \\
53\end{array}$ & $\begin{array}{l}4,725,086 \\
.00\end{array}$ & 33.7 & 43.09 \\
\hline 2002 & $\begin{array}{l}696,800 . \\
00\end{array}$ & $\begin{array}{l}321,37 \\
8.10\end{array}$ & 1018156 & $\begin{array}{l}9,993 . \\
55\end{array}$ & 0.981 & $\begin{array}{l}3,357,062 . \\
94\end{array}$ & $\begin{array}{l}6,912,381 \\
.25\end{array}$ & 48.5 & 31.56 \\
\hline 2003 & $\begin{array}{l}984,300 . \\
00\end{array}$ & $\begin{array}{l}241,68 \\
8.30\end{array}$ & 1225966 & $\begin{array}{l}7,537 . \\
35\end{array}$ & 0.614 & $\begin{array}{l}3,624,579 \\
49\end{array}$ & $\begin{array}{l}8,487,031 \\
.57\end{array}$ & 42.70 & 19.71 \\
\hline 2004 & $\begin{array}{l}1,032,70 \\
0.00\end{array}$ & $\begin{array}{l}351,30 \\
0.00\end{array}$ & 1426200 & $\begin{array}{l}11,25 \\
6.63\end{array}$ & 0.789 & $\begin{array}{l}3,903,758 . \\
69\end{array}$ & $\begin{array}{l}11,411,06 \\
6.91\end{array}$ & 34.21 & 24.63 \\
\hline 2005 & $\begin{array}{l}1,223,70 \\
0.00\end{array}$ & $\begin{array}{l}519,50 \\
0.00 \\
\end{array}$ & 1822100 & $\begin{array}{l}16,32 \\
5.96 \\
\end{array}$ & 0.895 & $\begin{array}{l}4,773,198 . \\
38\end{array}$ & $\begin{array}{l}14,572,23 \\
9.12\end{array}$ & 32.75 & 28.51 \\
\hline 2006 & $\begin{array}{l}1,290,20 \\
1.90\end{array}$ & $\begin{array}{l}552,38 \\
5.80 \\
\end{array}$ & 1938003 & $\begin{array}{l}17,91 \\
9.03\end{array}$ & 0.924 & $\begin{array}{l}5,940,236 . \\
97\end{array}$ & $\begin{array}{l}18,564,59 \\
4.73\end{array}$ & 31.99 & 28.50 \\
\hline 2007 & $1,589,27$ & 759,32 & 2450897 & 32,48 & 1.325 & $6,757,867$ & $20,657,31$ & 32.71 & 30.98 \\
\hline
\end{tabular}


Matching Credit With Season: An Issue for Non Performing Agricultural Loans in Nigeria

\begin{tabular}{|l|l|l|l|l|l|l|l|l|l|}
\hline & 0.00 & 3.00 & & 4.23 & & 73 & 7.67 & & \\
\hline 2008 & $2,117,36$ & $1,123,4$ & 3240820 & 65,39 & 2.017 & $7,981,397$. & $24,296,32$ & 32.85 & 34.66 \\
& 2,00 & 58.00 & & 9.01 & & 32 & 9.29 & & \\
\hline 2009 & $2,300,19$ & $1,152,7$ & 3452991 & 22,43 & 0.649 & $9,186,306$. & $24,794,23$ & 37.05 & 33.38 \\
& 4.30 & 96.50 & & 5.20 & & 05 & 8.66 & & \\
\hline 2010 & $3,310,34$ & 883,87 & 4194218 & 28,21 & 0.672 & $10,310,655$ & $33,984,75$ & 30.33 & 21.07 \\
& 3.38 & 4.50 & & 7.95 & & .64 & 4.13 & & \\
2011 & 3054333. & 918548 & 3972882 & 41169 & 0.103 & $11,590,120$ & $37,543,65$ & 30.87 & 23.12 \\
& 40 & .90 & .3 & .88 & & .18 & 4.70 & & \\
\hline
\end{tabular}

Source: Nigerian Bureau of Statistic, CBN Statistical Bulletin 2012

Note: SCTE=Share of Capital Expenditure in total Federal budget; $\mathrm{CE}=$ Capital Expenditure; RE=Recurrent Expenditure

TABLE 2: Default Claims (Filed by Lending Banks and Settled by CBN) and cumulative Amount and Number of Loans Guaranteed (analyzed by size) (1978- 2011)

\begin{tabular}{|c|c|c|c|c|c|c|c|}
\hline \multirow[t]{2}{*}{ Year } & \multirow[t]{2}{*}{$\begin{array}{l}\text { Agric } \\
\text { productivity } \\
(\mathrm{kg} / \mathrm{htr})\end{array}$} & \multicolumn{2}{|c|}{ Claims Filed } & \multicolumn{2}{|c|}{ Claims Settled } & \multicolumn{2}{|c|}{$\begin{array}{l}\text { cum. Loan Guaranteed } \\
\text { (analyzed by size) }\end{array}$} \\
\hline & & No. & $\begin{array}{ll}\text { Amt } & \left(\mathrm{N}^{\prime}\right. \\
000)\end{array}$ & No. & $\begin{array}{ll}\text { Amt } & \left(\mathrm{N}^{\prime}\right. \\
000)\end{array}$ & No. & Amt (N'000) \\
\hline 1978 & - & 0 & 0 & 0 & 0 & 341 & $11,284.40$ \\
\hline 1979 & - & 0 & 0 & 0 & 0 & 1,105 & $33,596.70$ \\
\hline 1980 & 1086 & 18 & 90 & 0 & 0 & 945 & $30,945.00$ \\
\hline 1981 & 1,655 & 38 & 613 & 0 & 0 & 1,295 & $35,642.40$ \\
\hline 1982 & 1,63 & 53 & 3427.6 & 36 & 241.3 & 1,076 & $31,763.90$ \\
\hline 1983 & 1,526 & 52 & 3680 & 24 & 147.9 & 1,333 & $36,307.50$ \\
\hline 1984 & 1,266 & 121 & 3880 & 0 & 0 & 1,642 & $24,654.90$ \\
\hline 1985 & 1,242 & 94 & 6636.5 & 93 & 431 & 3,337 & $44,243.60$ \\
\hline 1986 & 1,156 & 125 & 6385.4 & 0 & 0 & 5,203 & $68,417.40$ \\
\hline 1987 & 1,203 & 85 & 2155.6 & 68 & 534.1 & 16,209 & $102,152.50$ \\
\hline 1988 & 1,305 & 150 & 7933.1 & 52 & 380.2 & 24,538 & $118,611,00$ \\
\hline 1989 & 1,252 & 160 & 8526.6 & 48 & 191.2 & 34,518 & $129,300.30$ \\
\hline 1990 & 1,147 & 236 & 21756.8 & 51 & 770.1 & 30,704 & $98,494.40$ \\
\hline 1991 & 1,094 & 810 & 27972.5 & 67 & 253.7 & 22,014 & $82,107.40$ \\
\hline 1992 & 1,163 & 1362 & 31509.5 & 65 & 363.3 & 21,206 & $88,031.80$ \\
\hline 1993 & 1,153 & 998 & 28659.1 & 91 & 455.9 & 15,514 & $80,845.80$ \\
\hline 1994 & 1,132 & 1263 & 60525.9 & 56 & 222.6 & 16,572 & $103,186.00$ \\
\hline 1995 & 1,210 & 598 & 60149.9 & 130 & 2817.6 & 18,079 & $164,162.10$ \\
\hline 1996 & 1,220 & 442 & 5402.9 & 166 & 1090.4 & 18,036 & $225,502.50$ \\
\hline 1997 & 1,182 & 232 & 5181.6 & 690 & 6134.2 & 17,840 & $242,038.20$ \\
\hline 1998 & 1,201 & 78 & 2746.7 & 826 & 6906.2 & 14,637 & $215,697.20$ \\
\hline 1999 & 1,239 & 79 & 2488.8 & 498 & 5471.3 & 12,859 & $246,082.50$ \\
\hline 2000 & 1,171 & 173 & 8044.3 & 288 & 1691.2 & 14,102 & $361,450.40$ \\
\hline 2001 & 1,233 & 312 & 7216.4 & 436 & 6405 & 20,298 & $728,545.40$ \\
\hline 2002 & 1,255 & 206 & 6078.3 & 124 & 3210.2 & 23,681 & $1,051,589.80$ \\
\hline 2003 & 1,308 & 506 & 9236.3 & 168 & 3440.3 & 24,303 & $1,164,460.40$ \\
\hline 2004 & 1,372 & 213 & 11575.1 & 2065 & 97902 & 35,035 & $2,083,744.70$ \\
\hline 2005 & 1,421 & 8074 & 731846 & 2382 & 18782 & 46,238 & $3,046,738.50$ \\
\hline 2006 & 1,507 & 1215 & 129986 & 256 & 16344 & 54,032 & $4,263,060.30$ \\
\hline 2007 & 1,399 & 517 & 31791.9 & 165 & 23324 & 43,233 & $4,425,861.84$ \\
\hline 2008 & 1,598 & 529 & 46624 & 44 & 2033.8 & 52,787 & $6,721,074.56$ \\
\hline 2009 & 1,528 & 54 & 31375.1 & 38 & 14232 & 53,639 & $8,349,509.28$ \\
\hline 2010 & 1,413 & 410 & 74482.3 & 285 & 19103.6 & 50,849 & $7,740,507.63$ \\
\hline 2011 & - & 890 & 150345 & 24 & 9706.4 & 41,856 & $7,623,216.25$ \\
\hline & & 20093 & 1528323 & 9236 & 242586 & 740,056 & $49,772,826.56$ \\
\hline
\end{tabular}


Source: Development Finance Department, CBN.

Data on agricultural productivity were sourced from World Development Indicator and Global Financial Statistics.

\section{References}

[1]. Agriculture Credit Guarantee Scheme Fund (ACGSF):--- Consolidated statistics

[2]. Central Bank of Nigeria (CBN) Annual Report and Statement of Account (various issues).

[3]. Central Bank of Nigeria (2000). Annual Report Statement of Account December. Abuja, Nigeria.

[4]. Central Bank of Nigeria (2000). Statistical Bulletin, Vol.11, No.2, Abuja, Nigeria.

[5]. Central Bank of Nigeria (CBN) Annual Report and Statement of Account December, Abuja, Nigeria.

[6]. Central Bank of Nigeria (2005) Microfinance Policy, Regulatory and Supervisory Framework for Nigeria. pp22

[7]. Central Bank of Nigeria (2007) Agricultural Credit Guarantee Scheme Fund of Nigeria (ACGSF): An impact assessment. Study conducted by centre for Resource Analysis and Management for Governing Board of the ACGSF, Abuja.

[8]. Central Bank of Nigeria (1990). Agricultural Credit Guarantee Scheme Fund: Guidelines for the Agricultural Credit Guarantee Scheme. CBN, Abuja Nigeria

[9]. Central Bank of Nigeria (2007b): Statistical Bulletin. Central Bank of Nigeria.

[10]. Central Bank of Nigeria (2009): Comprehensive Guideline for Banks and State Government: Guidelines for Large Scale Agricultural Credit Scheme, LASACS. Central Bank of Nigeria, Abuja.

[11]. Central Bank of Nigeria (2012): Annual Report and statement of Accounts December. Abuja. Nigeria.

[12]. Central Bank of Nigeria (2013). Real Sector Interventions of the Central Bank of Nigeria. CBN, Abuja.

[13]. Central Bank of Nigeria (2012). Monetary, Credit, Foreign Trade and Exchange Policy Guidelines for Fiscal Years 2012/2013: Monetary Policy Circular N0.39. Central Bank of Nigeria, Abuja.

[14]. Central Bank of Nigeria (2013). Activities of the N200 Billion Commercial Agricultural Credit Scheme for the Month of March 2012. CBN, Abuja.

[15]. Ekong, C. N., \&Onye, K. U. (2012). Economic Development in Nigeria: The Basic Needs Approach. Journal of Economics and Sustainable Development, 3 (10), 54-65.

[16]. Eze, C.C., Lemchi, I. J., Ugochukwu, I. A., Eze, C.V., Awulonu, O.A.C., \&Okon, X.A. (2010). Agricultural Financing Policicies and Rural Development in Nigeria, A Paper Presented at the $84^{\text {th }}$ Annual Conference of the Agricultural Economics Society, $29^{\text {th }}$ $31^{\text {st }}$ March, Edinburgh.

[17]. Federal Government of Nigeria (1997).Agricultural Credit Guarantee Scheme, Decree No20 --- (1998): Agricultural Credit Guarantee Scheme (Amendment Decree No.18 of 1998.

[18]. Food Agricultural Organization (2006): Rapid Growth of Selected Asian Countries

[19]. Food Agricultural Organization (2012). The State of Food and Agriculture. Rome.

[20]. Global Agricultural Information Network (2011). Agricultural Finance and Development

[21]. Ike, N. D. (1986). The Problem of Loan Default in Nigerian Agriculture: An Economic and Financial Analysis.

[22]. Iganga, O. B., \&Umenhilin, O. D. (2011). The Impact of Federal Government Agricultural Expenditure on Agricultural Output in Nigeria. Journal Economics, 2 (2), 81-88.

[23]. International Food Policy Research Institute (2008): Agricultural Public Spending in Nigeria, Development Strategy and governance Division. IFPRI Discussion paper 00789.

[24]. Ojiako, A. I., \& Ogbukwa, C. B. (2012). Economic Analysis of Loan Repayment Capacity of Small-holder Cooperative Farmers in Yema North Local Government Area of Ogun State, Nigeria. African Journal of Agricultural Research, 7 (13), $2051-2062$.

[25]. Olaitan, M.A (2001) ''Emerging Issues on Micro Rural Financing in Nigeria', in Bullion, a Publication of the Central Bank of Nigeria, volume 25 No1 January/March, PP 64-71.

[26]. Olaitan, M.A (1997) Factors Influencing Repayment Pattern Under the ACGS in Ogun State, Nigeria Unpublished Ph.D Dissertation, University of Ibadan Nigeria.

[27]. Olaitan, M.A (2006). Finance for small and Medium Enterprises: Nigeria's Agricultural Credit Guarantee Scheme Fund. Journal of Farm Management, 3 (2), 1-9

[28]. Strategy Support Program, Brief No.2, International Food Policy Institute. Abuja, Nigeria.

[29]. World Bank (1998): Human Development Report. The World Bank, Washington, D.C. 